\title{
Comparison of protein and energy supplementation to mineral supplementation on feeding behavior of grazing cattle during the rainy to the dry season transition
}

\author{
Rita Kelly Couto Brandão ${ }^{1}$, Gleidson Giordano Pinto de Carvalho ${ }^{2 *}$, Robério Rodrigues Silva', \\ Daniel Lucas Santos Dias', Fabrício Bacelar Lima Mendes ${ }^{1}$, Túlio Otávio Jardim D’Almeida Lins', \\ George Abreu Filho', Sinvaldo Oliveira de Souza', Daniele Soares Barroso', Luana Marta de Almeida Rufino ${ }^{2}$ \\ and Manuela Silva Libânio Tosto ${ }^{2}$
}

\begin{abstract}
The aim of this study was to evaluate the effects of protein-energy or mineral supplementation on the ingestive behavior of dairy steers on pasture in the post-weaning phase during the rainy to dry season transition. Twenty-two $1 / 2$ Holstein-Zebu dairy steers with an average initial body weight of $234 \pm 16 \mathrm{~kg}$ were distributed into a completely randomized design into two groups: protein-energy supplementation and mineral supplementation offered ad libitum. The steers receiving protein-energy supplementation showed higher $(P<0.05)$ intake of dry matter $(D M)$ and neutral detergent fiber (NDF) than those fed diets composed of mineral salt only. In addition, the animals that received protein-energy supplementation had longer period in grazing and spent on average more time per period eating at the trough $(P<0.05)$, however no significant differences were observed in the time per period in rumination and time per period in idle $(P>0.05)$. The supply of protein-energy supplement does not change the feeding behavior, except for an increase in the time spent feeding at the trough. The intake of protein-energy supplement improved the of DM and NDF feed efficiencies in grazing cattle during the rainy to the dry season transition.
\end{abstract}

Keywords: Bite, Efficiency, Pasture, Rumination

\section{Background}

Tropical pastures are considered the main component of the cattle production system in Brazil and their quality and availability affect directly the productivity of animals. However, production is not constant due to climatic variations which change forage availability throughout the year with quantitative and qualitative alterations in forage, especially during the dry period (Almeida et al. 2014). Thus, in the wet-dry transition period of the year, the forage quality is reduced because of the greater lignification of the plant components, with a decrease in the

*Correspondence: gleidsongiordano@yahoo.com.br

2 Federal University of Bahia-UFBA, Salvador, Bahia, Brazil

Full list of author information is available at the end of the article leaf:stem ratio, an increase in dead material and reduction of crude protein, which lead to lower digestibility of the forages.

The supplementation of grazing cattle consists of the act of supplying a source of additional nutrients to the system, which may generate changes in the forage intake, concentration of nutrients, availability of dietary energy, magnitude of the pool of biochemical precursors of the metabolism and animal performance (Paulino et al. 2004). The need for providing protein, energy and mineral supplementation to grazing cattle and the amounts that are supplied depend on the goals of the system and planned weight gain at the property on the quality and availability of pasture dry matter (Barbosa et al. 2008). 
Moreover, rearing cattle on pasture is an activity characterized by factors linked to the environment, to the animal and to the pasture and their interactions may affect the search for food, in which the daily intake of forage is the key element for greater understanding of the feeding behavior (Palhano et al. 2007). Thus, the total forage intake by a grazing animal is the result of the accumulation of the forage consumed in each grazing action and of the frequency with which animals perform it during the time they spend feeding (Zanine et al. 2009). Through behavioral assessments, it is possible to evaluate the nutritional potential of diets and to adjust the animal feeding management aiming at better performance (Bastos et al. 2014).

The aim of this study was to evaluate the effect of protein-energy or mineral supplementation on the feeding behavior of dairy steers in their post-weaning phase on Brachiaria brizantha pastures during the wet-dry season transition.

\section{Methods}

The experiment was conducted on Princesa do Mateiro Farm, located in Ribeirão do Largo, Bahia, Brazil. Twentytwo $1 / 2$ crossbreed Holstein-Zebu steers with an average age of 10 months and an average initial body weight of $234.5 \pm 16.0 \mathrm{~kg}$ were used. The total experiment lasted 84 days, consisting of three sub-periods of 28 days.

The steers were weighed, identified at the beginning of the experiment and were randomly divided into two groups. The animals were allocated in a completely randomized design, with two types of supplementation and 11 replicates. The following treatments were tested: $1-$ protein-energy supplementation $0.4 \%$ of the body weight in supplement per day, balanced so as to meet the nutrient requirements for gain of 0,600 g day-1 (NRC 2001); and 2-mineral supplementation-mineral supplement offered ad libitum. The protein-energy supplement was supplied daily, at $1000 \mathrm{~h}$, in uncovered, collective plastic troughs with double access, and a linear dimension of 80 $\mathrm{cm}$ /animal (Tables 1 and 2).

The rotational stocking system was adopted in the pasture with Brachiaria brizantha cv. Marandu, in a area of 7.7 ha divided into six paddocks of equivalent areas. Thus, two paddocks were used per treatment and per experimental period. To avoid any effects from the pasture, animals from each treatment were rotated every 7 days across the paddocks.

The pasture was evaluated every 28 days (Table 3 ) and the availability of dry matter (DM) was determined following the method described by McMeniman (1997). The daily residual biomass (RB) was estimated according to the double-sampling method (Wilm et al. 1994). Before the cut, the DM of the biomass from the sample
Table 1 Proportion of ingredients of the supplements

\begin{tabular}{lll}
\hline Ingredient (\%) & $\begin{array}{l}\text { Protein-energy } \\
\text { supplement }\end{array}$ & $\begin{array}{l}\text { Mineral } \\
\text { supplement }\end{array}$ \\
\hline Corn & 45.0 & - \\
Soybean meal & 45.4 & - \\
Urea + AS $^{a}$ & 5.0 & - \\
Mineral mix & 4.6 & 100.0 \\
\hline
\end{tabular}

a Urea + ammonium sulfate (9:1)

b Composition of the mineral mix: calcium $235 \mathrm{~g}$; phosphorus $160 \mathrm{~g}$; magnesium $16 \mathrm{~g}$; sulfur $12 \mathrm{~g}$; cobalt $150 \mathrm{mg}$; copper $1600 \mathrm{mg}$; iodine $190 \mathrm{mg}$; manganese 1400 mg; iron 1000 mg; selenium 32 mg; zinc 6000 mg; 1120 mg; fluorine (maximum) $1600 \mathrm{mg}$

Table 2 Chemical composition of the Brachiaria brizantha pasture and the protein-energy supplement

\begin{tabular}{lll}
\hline Item (g/kg DM) & $\begin{array}{l}\text { Brachiaria } \\
\text { brizantha }\end{array}$ & $\begin{array}{l}\text { Protein-energy } \\
\text { supplement }\end{array}$ \\
\hline $\begin{array}{l}\text { Dry matter (DM; in g/kg natural } \\
\text { matter) }\end{array}$ & 285.2 & 878.5 \\
Organic matter & 908.9 & 897.6 \\
Crude protein & 100.0 & 480.0 \\
Ether extract & 24.6 & 27.2 \\
Neutral detergent fiber cor- & 697.2 & 227 \\
$\quad$ rected for ash and protein & & \\
Acid detergent fiber & 401.2 & 87.7 \\
Total carbohydrates $^{\mathrm{a}}$ & 781.9 & 388.2 \\
Non-fibrous carbohydrates $^{\mathrm{b}}$ & 155.4 & 158.4 \\
Total digestible nutrients $^{\mathrm{c}}$ & 519.9 & 600.0 \\
\hline
\end{tabular}

a Calculated by the equation proposed by Hall (2003)

b Calculated based on the equation proposed by Sniffen et al. (1992)

c Calculated based on the equation proposed by Weiss (1999)

was estimated visually and the equation proposed by Gardner (1986) was utilized to calculate the forage biomass, expressed in $\mathrm{kg} / \mathrm{ha}$.

The samples were collected, weighed and homogenized and composite samples were made for the separation of the forage components (leaf, stem and dead material). After the separation, each forage component was weighed to determine the morphological composition in percentage.

An external marker, titanium dioxide was utilized to estimate the concentrate intake. The marker was supplied at $10 \mathrm{~g} /$ animal day $^{-1}$, mixed daily with the concentrate, for 7 days (Detmann et al. 2012). To estimate the voluntary intake of roughage, the indigestible neutral detergent fibre (iNDF) internal marker was used, obtained after $288 \mathrm{~h}$ of ruminal incubation (method INCT-CA F-009/1; Detmann et al. 2012). The forage samples collected by the simulated-grazing method were obtained according to Johnson (1978). 
Table 3 Availability of dry matter (DM), residual biomass (RB), daily accumulation rate (DAR), forage allowance (FA), leaf:stem ratio and stocking rate of Brachiaria brizantha in the three experimental periods

\begin{tabular}{lcccc}
\hline Item & \multicolumn{2}{l}{ Period } & & Mean \\
\cline { 2 - 4 } & $\begin{array}{l}\text { 1st } \\
\text { (March) }\end{array}$ & $\begin{array}{l}\text { 2nd } \\
\text { (April) }\end{array}$ & $\begin{array}{l}\text { 3rd } \\
\text { (may) }\end{array}$ & \\
\hline $\begin{array}{l}\text { Availability of DM (kg DM/ } \\
\text { ha) }\end{array}$ & 5285.0 & 4273.8 & 3859.8 & 4472.8 \\
RB (kg DM/ha/day) & 179.1 & 152.6 & 137.8 & 156.5 \\
DAR (kg DM/ha/day) & 20.2 & 18.3 & 13.6 & 17.3 \\
FA (kg DM/100 kg body & 15.6 & 8.5 & 5.9 & 10.0 \\
weight/day) & & & & \\
$\begin{array}{l}\text { Leaf:stem ratio } \\
\begin{array}{l}\text { Stocking rate (animal unit/ } \\
\text { ha) }\end{array}\end{array}$ & 0.97 & 0.81 & 0.50 & 0.76 \\
\hline
\end{tabular}

a Determined as described by McMeniman (1997)

b Estimated according to the double-sampling method (Wilm et al. 1994)

c Determined by the equation proposed by Campbell (1966)

d Determined by the equation proposed by Prohmann et al. (2004)

e Considering the animal unit $450 \mathrm{~kg}$ body weight

Forage samples were pre-dried in a forced-ventilation oven $\left(55-60{ }^{\circ} \mathrm{C}\right)$ and ground in a Wiley mill to 1 and $2 \mathrm{~mm}$ sieve for laboratory analyses. Dry matter (DM; method INCT-CA G-003/1); organic matter (OM; method INCT-CA M-001/1); crude protein (CP; method INCT-CA N-001/1; ether extract (EE; method INCT-CA G-005/1); insoluble neutral detergent fiber corrected for ash and protein (NDFap): methods INCT-CA F-002/1, INCT-CA M-002/1 and INCT-CA N-004/1); and ADF (method INCT-CA F-004/1), contents were determined according to the techniques described by Detmann et al. (2012).

Non-fibrous carbohydrates corrected for ash and protein (NFCap) were determined by the equation recommended by Hall (2003). Total carbohydrates were calculated using the equation proposed by Sniffen et al. (1992) and total digestible nutrients (TDN), using the NDF corrected for ash and protein (Weiss 1999).

The evaluations of feeding behavior was evaluated in the 35th and 42nd day of the experimental period, with observations performed every $5 \mathrm{~min}$, according to the method described by Silva et al. (2006), for a total period of $24 \mathrm{~h}$ per day by two observers trained, strategically placed so as not to disturb the animals. The following behavioral variables were observed: grazing time, rumination time, idle time and time spent feeding at the trough. The behavioral variables were considered mutually exclusive, as defined by Pardo et al. (2003). Time spent on feeding and rumination were calculated as a function of the intakes of DM and NDF ( $\mathrm{min} / \mathrm{kg}$ DM or
NDF). The number of rumination chews and the time spent on ruminating each ruminal cud, for each animal, were obtained according to Burger et al. (2000) and the discretization of time series was performed as described by Silva et al. (2006).

The bite rate of the steers from each group was estimated as the time spent by the animal to perform 20 bites (Hodgson 1982). To calculate the bite mass, the daily intake was divided by the total number of daily bites (Jamieson and Hodgson 1979). The results of biting and swallowing observations were recorded in six occasions throughout the day, according to Baggio et al. (2009).

The variables $g$ of DM and $g$ of NDF per meal were obtained by dividing the average individual intake of each fraction by the number of feeding periods per day (in $24 \mathrm{~h}$ ). The feed and rumination efficiencies, expressed in $\mathrm{g} \mathrm{DM} / \mathrm{h}$ and $\mathrm{g} N \mathrm{ND} / \mathrm{h}$, were determined by dividing the average daily intake of DM and NDF by the total time spent feeding and/or ruminating in $24 \mathrm{~h}$, respectively. The variables $g$ of DM and NDF/cud were obtained by dividing the average individual intake of each fraction by the number of cuds ruminated per day (in $24 \mathrm{~h}$ ).

The data were interpreted by analyses of variance, using the System for Statistical and Genetic Analyses (Sistema de Análises Estatísticas e Genéticas - SAEG; UFV, 2001), at $5 \%$ probability level.

\section{Results}

The steers that received protein-energy supplementation consumed more $(\mathrm{P}<0.05) \mathrm{DM}$ and NDFap than those fed only the mineral mix (Table 4). No significant differences were observed $(P>0.05)$ for the times spent on the grazing, idle and rumination activities, however the steers receiving protein-energy supplementation spent more time at the trough $(\mathrm{P}<0.05)$ than the animals that received only mineral supplementation Additionally, no significant differences were observed $(P>0.05)$ for the total feeding and chewing times (Table 4).

The times spent feeding (grazing + trough) in min per $\mathrm{kg}$ of DM and $\mathrm{kg}$ of NDFap were longer $(\mathrm{P}<0.05)$ in the animals fed the mineral supplement as compared with those that received the protein-energy supplement, which may be due to the grazing time. In addition, the rumination time in min per $\mathrm{kg}$ of DM was shorter $(\mathrm{P}<0.05)$ in the group that received protein-energy supplement compared with the group that received only mineral supplement, however, no differences were observed $(P>0.05)$ for the rumination time in $\mathrm{min} / \mathrm{kg}$ NDFap (Table 4).

The animals receiving protein-energy supplementation showed higher bite rates and a lower number of bites per swallow $(\mathrm{P}<0.05)$ compared with the animals fed mineral supplementation only. On the other hand, there were 
Table 4 Intakes of dry matter (DM) and neutral detergent fiber corrected for ash and protein (NDFap), times spent on grazing, rumination, idle and feeding at the trough, total feeding and chewing times and feeding and rumination times as a function of DM and NDFap intakes by steers on pasture receiving protein-energy or mineral supplementation

\begin{tabular}{|c|c|c|c|c|}
\hline \multirow[t]{2}{*}{ Item $^{a}$} & \multicolumn{2}{|l|}{ Supplement } & \multirow[t]{2}{*}{ S.E.M ${ }^{c}$} & \multirow[t]{2}{*}{$P$ value } \\
\hline & Protein-energy & Mineral & & \\
\hline & $\mathrm{kg} / \mathrm{day}$ & & & \\
\hline DM intake & 8.1 & 6.3 & 1.81 & $<0.001$ \\
\hline NDFap intake & 4.7 & 4.0 & 1.41 & 0.016 \\
\hline \multirow[t]{2}{*}{ Item $^{a}$} & \multicolumn{2}{|l|}{ Supplement } & \multirow[t]{2}{*}{ S.E.Mc } & \multirow[t]{2}{*}{$P$ value } \\
\hline & $\begin{array}{l}\text { Protein-energy } \\
\text { (Min/day) }\end{array}$ & Mineral & & \\
\hline Grazing $^{a}$ & 618.9 & 653.7 & 14.19 & 0.107 \\
\hline $\mid d e^{a}$ & 413.9 & 395.0 & 14.93 & 0.423 \\
\hline Rumination $^{\mathrm{a}}$ & 376.4 & 385.0 & 16.80 & 0.768 \\
\hline Trough $^{\mathrm{a}}$ & 30.9 & 6.2 & 7.79 & $<0.001$ \\
\hline $\begin{array}{l}\text { Total feeding } \\
\text { time }^{a}\end{array}$ & 649.8 & 653.7 & 14.34 & 0.852 \\
\hline $\begin{array}{l}\text { Total chewing } \\
\text { time }^{\mathrm{a}}\end{array}$ & 1026.1 & 1045.0 & 16.76 & 0.350 \\
\hline \multirow[t]{2}{*}{ Item $^{a}$} & \multicolumn{2}{|l|}{ Supplement } & \multirow[t]{2}{*}{ S.E.Mc } & \multirow[t]{2}{*}{$\mathrm{P}$ value } \\
\hline & $\begin{array}{l}\text { Protein-energy } \\
\text { (Min/kg DM) }\end{array}$ & Mineral & & \\
\hline Feeding $^{b}$ & 80.1 & 103.1 & 8.70 & $<0.001$ \\
\hline Rumination $^{\text {b }}$ & 46.4 & 60.7 & 8.37 & 0.044 \\
\hline \multirow[t]{2}{*}{ Item $^{a}$} & \multicolumn{2}{|l|}{ Supplement } & \multirow{2}{*}{\multicolumn{2}{|c|}{ S.E.Mc $P$ value }} \\
\hline & $\begin{array}{l}\text { Protein-energy } \\
\text { (Min/kg NDFap) }\end{array}$ & Mineral & & \\
\hline Feeding $^{b}$ & 138.8 & 164.2 & 10.63 & 0.004 \\
\hline Rumination $^{\text {b }}$ & 80.4 & 96.7 & 10.71 & 0.129 \\
\hline
\end{tabular}

a The behavioral variables were considered mutually exclusive, as defined by Pardo et al. (2003)

b Calculated as a function of the intakes of DM and NDF

c S.E.M = standard error of the mean

no significant differences $(P>0.05)$ between the types of supplement for bite mass, time per swallowed cud and number of bites per day (Table 5 ).

The steers that received protein-energy supplement showed a higher $(P<0.05)$ number of grazing and idle periods and periods feeding at the trough (Table 6). No significant differences were detected between the treatments for the number of rumination periods $(\mathrm{P}>0.05)$. In addition, the animals that received protein-energy supplementation spent a shorter time per grazing period and a longer average time per period feeding at the trough $(P<0.05)$. No significant differences $(P>0.05)$
Table 5 Bite-related aspects of dairy steers receiving protein-energy or mineral supplementation on Brachiaria brizantha cv. Marandu pastures

\begin{tabular}{|c|c|c|c|c|}
\hline \multirow[t]{2}{*}{ Item } & \multicolumn{2}{|l|}{ Supplement } & \multirow[t]{2}{*}{ S.E.M ${ }^{d}$} & \multirow[t]{2}{*}{$P$ value } \\
\hline & Protein/energy & Mineral & & \\
\hline Bite rate (number/s) ${ }^{a}$ & 0.7 & 0.5 & 0.68 & 0.012 \\
\hline Bite mass $(g / D M)^{b}$ & 0.3 & 0.3 & 0.53 & 0.537 \\
\hline $\begin{array}{l}\text { Bites per swallow } \\
\text { (number) }^{c}\end{array}$ & 23.0 & 28.4 & 4.04 & 0.004 \\
\hline $\begin{array}{l}\text { Time per cud swallowed } \\
\text { (seconds) })^{c}\end{array}$ & 59.0 & 52.5 & 17.79 & 0.844 \\
\hline Bites per day (number) ${ }^{c}$ & 26,849 & 20,896 & 135.78 & 0.068 \\
\hline
\end{tabular}

a Estimated as the time spent by the animal to perform 20 bites (Hodgson 1982)

b Daily intake divided by the total number of daily bites (Jamieson and Hodgson 1979)

c Were recorded in six occasions throughout the day according to Baggio et al. (2009)

d S.E.M = standard error of the mean

were observed for time spent per rumination period (Table 6).

The intake in $\mathrm{g} D M /$ meal was not affected by the supplement $(\mathrm{P}>0.05)$, however the intake in $\mathrm{g} \mathrm{NDF} / \mathrm{meal}$ was shorter in animals supplemented with proteinenergy. The rumination efficiency in $\mathrm{kg} \mathrm{DM} / \mathrm{h}$ and the rumination in $\mathrm{g} D M /$ cud was higher $(\mathrm{P}<0.05)$ in the animals consuming protein-energy supplement, furthermore the feed efficiency was higher $(\mathrm{P}<0.05)$ in these animals (Table 7).

\section{Discussion}

In the animals consuming protein-energy supplementation, the association between the non-fibrous components and nitrogen compounds in the rumen provide the microrganisms with energy for microbial production and growth, improving the utilization of the fiber and increasing the digestibility of nutritional components. This allows for a higher forage intake, demonstrating a positive association effect between the supplement and the forage.

In the present study, the pasture showed a reduced leaf: stem ratio, which averaged $0.73 \%$ (Table 3 ). In this situation, the animals tend to spend more time on grazing, seeking the most digestible parts of the plants. Additionally, because it is the most nutritive and palatable component of plants, the animals prefer the leaf blade; therefore, the animal decisions for the search for forage are preferentially based on the search for this component (Teixeira et al. 2010).

According Hodgson (1990), grazing times longer than 8-9 h per day, as observed in this study, may be indicative of limiting sward conditions to forage intake, because 
Table 6 Number and time per period of feeding-related behavioral activities by dairy steers receiving protein-energy or mineral supplementation on Brachiaria brizantha cv. Marandu pastures

\begin{tabular}{|c|c|c|c|c|}
\hline \multirow[t]{2}{*}{ Item } & \multicolumn{2}{|l|}{ Supplement } & \multirow[t]{2}{*}{ S.E.M.' } & \multirow[t]{2}{*}{$P$ value } \\
\hline & Protein-energy & Mineral & & \\
\hline Number of grazing periods ${ }^{\mathrm{a}}$ & 13.4 & 10.1 & 3.58 & 0.027 \\
\hline Number of rumination periods ${ }^{\mathrm{a}}$ & 15.4 & 13.8 & 2.92 & 0.088 \\
\hline Number of idle periods ${ }^{\mathrm{a}}$ & 23.5 & 19.6 & 4.00 & 0.032 \\
\hline Number of periods feeding at the trough ${ }^{a}$ & 2.4 & 0.8 & 1.61 & $<0.001$ \\
\hline Average time per grazing period (minutes) & 48.2 & 69.6 & 8.43 & 0.008 \\
\hline Average time per rumination period (minutes) ${ }^{\mathrm{b}}$ & 24.5 & 28.4 & 4.83 & 0.120 \\
\hline Average time per idle period (minutes) ${ }^{b}$ & 18.2 & 20.9 & 4.72 & 0.246 \\
\hline Average time per trough period (minutes) ${ }^{b}$ & 13.6 & 7.3 & 3.56 & $<0.001$ \\
\hline
\end{tabular}

a Performed by counting periods of grazing, rumination and feeding in the trough (Silva et al. 2006)

b Obtained by dividing the daily times for each activity by the number of times the same activity (Smith et al. 2006)

c S.E.M = standard error of the mean

Table 7 Intakes of dry matter (DM) and neutral detergent fiber corrected for ash and protein (NDF), feed efficiency (kg DM and NDF/h) and rumination efficiency (kg DM and NDF/cud) of dairy crossbred steers on pasture receiving protein-energy or mineral supplementation

\begin{tabular}{|c|c|c|c|c|}
\hline \multirow[t]{2}{*}{ Item } & \multicolumn{2}{|l|}{ Supplement } & \multirow[t]{2}{*}{ S.E.M ${ }^{d}$} & \multirow[t]{2}{*}{$P$ value } \\
\hline & Protein/energy & Mineral & & \\
\hline & Intake ${ }^{a}$ & & & \\
\hline g DM/meal & 535.6 & 662.0 & 29.98 & 0.180 \\
\hline \multirow[t]{2}{*}{ g NDF/meal } & 138.2 & 180.5 & 10.31 & $<0.001$ \\
\hline & Feed efficiency ${ }^{b}$ & & & \\
\hline kg DM/h & 0.80 & 0.58 & 0.897 & 0.023 \\
\hline \multirow[t]{2}{*}{$\mathrm{kg} \mathrm{NDF/h}$} & 0.46 & 0.36 & 0.534 & 0.001 \\
\hline & Rumination effici & & & \\
\hline kg DM/h & 1.35 & 1.09 & 1.210 & 0.067 \\
\hline \multirow[t]{2}{*}{$\mathrm{kg} \mathrm{NDF/h}$} & 0.78 & 0.67 & 0.746 & 0.217 \\
\hline & Rumination ${ }^{c}$ & & & \\
\hline g DM/cud & 17.53 & 14.13 & 3.612 & 0.012 \\
\hline g NDF/cud & 10.16 & 8.76 & 2.995 & 0.111 \\
\hline
\end{tabular}

a Obtained by dividing the average individual intake of each fraction by the number of feeding periods per day

${ }^{b}$ Obtained by dividing the average daily intake of DM and NDF by the total time spent feeding and/or ruminating in $24 \mathrm{~h}$

c Obtained by dividing the average individual intake of each fraction by the number of cuds ruminated per day

${ }^{d}$ S.E.M. $=$ standard error of the mean

the stem density found in the pasture may act as a barrier to defoliation, reducing the ease at which the animal harvests the forage. This in turn promotes an increase in the duration of grazing, which may lead to a restriction of intake and the daily nutrient requirement not being met. Stivanin et al. (2014) evaluated the ingestive behavior of hoggets which received different types of supplement on ryegrass pasture, and observed that the daytime grazing is shorter when the hoggets receive supplements, regardless of the type of supplement.

Macedo Júnior et al. (2007) stated that effectiveness is the ability of a feedstuff or a diet to provide the motor and physical activity of the gastrointestinal tract, because ruminants retain fiber selectively in their rumen for the appropriate time for digestion. This occurs due to the consumption of long particles during feeding, which provide the necessary stimulation to trigger the rumination activity.

Because it has smaller and more digestible particles, the protein-energy supplement may reduce the rumination activity (Table 4) of the animals, which was demonstrated by Burger et al. (2000), who stated that concentrate and finely ground or pelleted hays reduce the rumination time, whereas roughages with a high cell wall content tend to increase it. The same way, Correia et al. (2015) evaluated feeding behavior of feedlot-finished young bulls fed diets containing peanut cake observed that the number of rumination periods increased with increasing dietary fiber content, reflecting the need for better processing of ruminal digesta to increase digestive efficiency.

The total availability of dry matter $(4472.82 \mathrm{~kg} / \mathrm{ha}$; Table 3) was not limiting to intake; however, factors related to the animal, depending on the quality of the consumed forage, may limit the DM intake. The low leaf:stem ratio found in this study might have caused the lower bite rate by the animals that received mineral supplementation: 0.70 and $0.53(\mathrm{n} / \mathrm{s})$ for the proteinenergy and mineral supplementations, respectively (Table 5). This lower bite rate observed for the animals that received only mineral supplementation may be explained by the fact that they spent more time selecting the most nutritive parts of the forage to meet their nutritional requirements, which increased the time spent 
on this activity and consequently the number of bites per swallow.

The bite rate is a measure that allows us to estimate how easily the forage is seized and, according to Hodgson (1985), the bite mass is the most important variable in the determination of the intake of grazing animals, affected by the structure of the forage sward. Almeida et al. (2014) evaluated the ingestive behavior of grazing heifers receiving crude glycerin supplementation during the dry-rainy season transition, observed that the addition of glycerin decreases and bite rate increases mass per bite in heifers supplemented during the dry-rainy season transition.

The highest number of grazing periods (Table 6), observed for the steers that received protein-energy supplementation in relation to those fed mineral supplement-13.36 and 10.12, respectively-evidence that the steers that consumed only mineral supplement had more intense grazing periods (TGP $=69.6 \mathrm{~min}$ ), than the other groups ( $\mathrm{TGP}=48.2 \mathrm{~min}$ ).

The longest average time per grazing period, observed in the group that received mineral supplement, can be explained by the greater selectivity during grazing, since the amount of dry matter and the availability of green leaves accessible on the pasture surface affect the time of permanence of ruminants in the search and harvest of food. Since the animal takes longer to stop grazing, due to the rumen fill (Trevisan et al. 2005), this led to a lower number of grazing periods (NGP) and consequently lower number of idle periods (NIP). Thus, this result is explained by the fact that the times in each period are the result of the total time spent on the activity division by the number of periods in which the activity.

The animals in the protein-energy supplement group received an additional uptake of nutrients originating from the supplement, their daily metabolic requirements were met faster than those of the animals that received only mineral supplement. According to Santana Júnior et al. (2013), the supply of concentrate reduces the time on search for forage and consequently the rumination time, thereby increasing the number of idle periods.

The higher intake of NDF ( $\mathrm{g} / \mathrm{meal})$ by the steers that received mineral supplement $(180.5 \mathrm{~g})$ in relation to those that received protein supplement (138.2 g) was because the steers that received mineral supplement had only forage as food and when they grazed they did not consume only leaves, since the leaf:stem ratio was low $(0.76 \%)$, that caused them to consume stems and dead materials, which then increased the amount of ingested fiber. Diets with lower percentages of NDF provide a higher dry matter intake, requiring a shorter total feeding time per $\mathrm{kg}$ of DM by the animal, which indicates better feed and rumination efficiencies as a function of DM intake and according to Nicory et al. (2015) rumination efficiency is an important mechanism to evaluate the use of low-digestibility feeds.

\section{Conclusion}

In general, the supply of a protein-energy supplement does not change the feeding behavior of the animals; however, it increases the time spent feeding at the trough. The consumption of protein-energy supplement during the wet-dry season transition improves the feed efficiencies of DM and NDF.

\section{Authors' contributions}

RB conduct experiment activities and writing of the manuscript. GC and RS: advisors and supervisors of all activities. DD, FM, TL, GAF, SS and DB conduct experiment activities. LR and MT correction and writing of the manuscript. All authors read and approved the final manuscript.

\section{Author details \\ ${ }^{1}$ Southwest Bahia State University-UESB, Itapetinga, Bahia, Brazil. ${ }^{2}$ Federal University of Bahia-UFBA, Salvador, Bahia, Brazil.}

\section{Competing interests}

The authors declare that they have no competing interests.

Received: 22 October 2015 Accepted: 16 June 2016

Published online: 30 June 2016

\section{References}

Almeida VVS, Silva RR, Visintin ACO, Queiroz AC, Silva FF, Sampaio CB, Lisboa MM, Mendes FBL, Lins TOJD (2014) Ingestive behavior of grazing heifers receiving crude glycerin supplementation during the dry-rainy season transition. Chilean J Agric Res 74(3):286-292. doi:10.4067/ S0718-58392014000300006

Baggio C, Carvalho PCF, Da Silva JLS, Anghinoni I, Lopes MLT, Thurow JM (2009) Displacement patterns and herbage capture by steers in Italian ryegrass and black oat pastures managed under different heights in integrated crop-livestock system. R Bras Zootec 38(2):215-222. doi:10.1590/ S1516-35982009000200001

Barbosa FA, Graça DS, Guimarães PHS, Silva Junior FF (2008) Economic analysis of protein and energy supplementation of steers during the transition period between the rainy and dry seasons. Arq Bras Med Vet Zootec 60(4):911-916. doi:10.1590/S0102-09352008000400021

Bastos MPV, Carvalho GGP, Pires AJV, Silva RR, Eustáquio Filho A, Santos EJ, Chagas DMT, Barroso DS, Abreu Filho G (2014) Ingestive behavior and nitrogen balance of confined Santa Ines lambs fed diets containing soybean hulle. Asian-Australas J Anim Sci 27(1):24-29. doi:10.5713/ajas.2013.13076

Burger PJ, Pereira JC, Queiroz AC, Da Silva JFC, Valadares Filho SC, Cecon PR, Casali ADP (2000) Ingestive behavior in Holstein calves fed diets with different concentrate levels. R Bras Zootec 29(1):236-242. doi:10.1590/ S1516-35982000000100031

Campbell AG (1966) Grazed pastures parameters; II. Pasture dry-matter production and availability in a stocking rate and grazing management experiment with dairy cows. J Agr Sci 67(2):211-216. doi:10.1017/ S0021859600068295

Correia BR, Carvalho GGP, Oliveira RL, Pires AJV, Ribeiro OL, Silva RR, Leão AG, Rodrigues CS (2015) Feeding behavior of feedlot-finished young bulls fed diets containing peanut cake. Trop Anim Health Prod 47(6):1075-1081

Detmann E, Souza MA, Valadares Filho SC, Queiroz AC, Berchielli TT, Saliba EOS, Cabral LS, Pina DS, Ladeira MM, Azevedo JAG (2012) Métodos para análise de alimentos. Suprema, Visconde do Rio Branco, p 214

Gardner AL (1986) Técnicas de pesquisa em pastagem e aplicabilidade de resultados em sistema de produção. IICA/EMBRAPA CNPGL. p 197-205

Hall MB (2003) Challenges with non-fiber carbohydrate methods. J Anim Sci 81(12):3226-3232 
Hodgson J (1982) Ingestive behavior. In: Leaver JD (ed) Herbage intake handbook. Hurley, British Grassland Society. p 113

Hodgson J (1985) The control of herbage intake in the grazing ruminant. Proc Nutr Soc 44:339-346

Hodgson J (1990) Grazing management science into practice. Longman scientific and technical, London, p 203

Jamieson WS, Hodgson J (1979) The effect of variation in sward characteristics upon the ingestive behavior and herbage intake of calves and lambs under continuous stocking management. Grass For Sci 34(4):273-282

Johnson AD (1978) Sample preparation and chemical analysis of vegetation. In: Manetje LT (ed.) Measurement of grassland vegetation and animalproduction. Aberustwyth: Commonwealth Agricultural Bureaux. p 96-102

Macedo Júnior GL, Zanine AM, Borges I, Pérez JRO (2007) Qualidade da fibra para a dieta de ruminantes. Cienc Anim 17(1):7-17

McMeniman NP (1997) Methods of estimating intake of grazing animals. In: Reunião Anual da Sociedade Brasileira de Zootecnia, Simpósio sobre Tópicos Especiais em Zootecnia, 34, 1997, Juiz de Fora. Anais Sociedade Brasileira de Zootecnia, p 131-168

Nicory IMC, Carvalho GGP, Ribeiro OL, Silva RR, Tosto MS, Costa Lopes LS, Souza FNC, Nascimento CO (2015) Ingestive behavior of lambs fed diets containing castor seed meal. Trop Anim Health Prod 47:939-944. doi:10.1007/s11250-015-0812-9

NRC — National Research Council (2001) Nutrient requirements of dairy cattle.7.ed. Washington, D.C.: National Academic Press, p 381

Palhano AL, Carvalho PCF, Dittrich JR, Moraes A, Da Silva SC, Monteiro ALG (2007) Forage intake characteristics on mombaçagrass pastures grazed by Holstein heifers. R Bras Zootec 36(4):1014-1021. doi:10.1590/ S1516-35982007000500005

Pardo RMP, Fisher V, Balbinotti M, Moreno CB, Ferreira EX, Vinhas RI, Monks PL (2003) Diurnal ingestive behavior of grazing steers fed increasing levels of energy supplementation. R Bras Zootec 32(6):1408-1418. doi:10.1590/ S1516-35982003000600016

Paulino MF, Figueiredo DM, Moraes EHBK, Porto MO, Sales MFS, Acedo TS, Villela SDJ, Valadares Filho, SC (2004) Suplementação de Bovinos em pastagens: uma visão sistêmica. In: simpósio de Produção de Gado de Corte, 4, 2004, Viçosa, MG. Anais Viçosa, MG: Universidade Federal de Viçosa. p 93-144
Prohmann PEF, Branco AF, Cecato U, Jobim CC, Guimarães KC, Ferreira RA (2004) Cattle supplementation on coastcross pasture (Cynodon dactylon (L.) Pers) during the winter. R Bras Zootec 33(4):801-810. doi:10.1590/ S1516-35982004000300029

Santana Júnior HA, Silva RR, Carvalho GGP, Cardoso EO, Mendes FBL, Pinheiro AA, Abreu Filho G, Dias DLS, Barroso DS, Silva FF, Trindade Júnior G (2013) Ingestive behavior of supplemented grazing heifers on compensatory nutrition. Arch Zootec 62(237):62-71. doi:10.4321/ S0004-05922013000100007

Silva RR, Prado IN, Carvalho GGP, Franco IL, Almeida VS, Cardoso CP, Ribeiro MHS (2006) Bovine intake behavior methodological aspects. Arch Zootec 55(211):293-296

Smith DG, Cuddeford D, Pearson RA (2006) The effect of extended grazing time and supplementary forage on the dry matter intake and foraging behaviour of cattle kept under traditional African grazing systems. Trop Anim Health Prod 38:75-84. doi:10.1007/s11250-006-4342-3

Sniffen CJ, O'Connor JP, Van Soest PJ, Fox DG, Russell JB (1992) A net carbohydrate and protein system for evaluating cattle diets: I- carbohydrate and protein availability. J Dairy Sci 70(11):3562-3577

Stivanin SCB, Rocha MG, Potter L, Hampel VS, Oliveira RA, Bergoli TL (2014) Ingestive behavior of hoggets given different types of supplement on ryegrass pasture. Acta Sci Anim Sci 36(1):101-107. doi:10.4025/actascianimsci.v36i1.21641

Teixeira FA, Marques JA, Silva FF, Pires AJV (2010) Feeding behavior and cattle displacement pattern in tropical pastures. Arch Zootec 59(R):57-70

Trevisan NB, Quadros FLF, Silva ACF, Bandinelli DG, Martins CEN (2005) Effect of structure of a cool season pasture on grazing behaviour of beef steers. $R$ Bras Zootec 34:774-780. doi:10.1590/S1516-35982005000300008

Weiss WP (1999). Energy prediction equations for ruminant feeds. In: Cornell nutrition conference for feed manufacturers, 61, 1999, Ithaca. Proceedings Ithaca: Cornell University. p 176-185

Wilm HG, Costello DF, Klipple GE (1994) Estimating forage yield by the double sampling method. J Am Soc Agron 36:194-203

Zanine AM, Vieira BR, Ferreira DJ, Vieira AJM, Lana RP, Cecon PR (2009) Ingestive behavior of Gyr $\times$ Holstein cows grazing Brachiaria brizantha and Coastcross pastures. R Bras Saúde Prod Anim 10(1):85-95

\section{Submit your manuscript to a SpringerOpen ${ }^{\odot}$ journal and benefit from:}

- Convenient online submission

- Rigorous peer review

- Immediate publication on acceptance

- Open access: articles freely available online

- High visibility within the field

- Retaining the copyright to your article

Submit your next manuscript at springeropen.com 